\title{
Magyarországi C-vírus-hepatitises betegek vírustípus- és szubtípusmegoszlásának elemzése
}

\author{
Gervain Judit dr. \\ Fejér Megyei Szent György Egyetemi Oktató Kórház, \\ I. Belgyógyászat/Hepato-Pancreatológia és Pécsi Tudományegyetem, Általános Orvostudományi Kar, \\ Laboratóriumi Medicina Intézet Molekuláris Diagnosztikai Oktató Laboratóriuma, Székesfehérvár
}

\begin{abstract}
Bevezetés: A hepatitis C-vírus (HCV) nagy szerkezeti variabilitást mutat. A genom szekvenálása és filogenetikai analízise alapján 7 típusa és 67 szubtípusa különíthető el, melyek földrajzi megoszlása különböző. A 2014-ben bevezetett direkt ható antivirális terápia (DAA) alkalmazása óta meghatározásuk kiemelten fontossá vált, mivel a gyógyszerek típusa, dózisa, a kezelések optimális időtartama genotípus/szubtípus függő.

Célkitüzés: Magyarországon 1992-ben kezdődött a krónikus C-vírus-hepatitises betegek kezelése, az ehhez szükséges speciális diagnosztikát Molekuláris Diagnosztikai Laboratóriumunkban vezettük be. Meghatároztuk a magyarországi HCVIb NS5A/PKR-BR régiójának nukleotidszekvenciáját és a magyarországi betegekből izolált vírustípus- és szubtípus-előfordulást. A jelen összefoglalóban 6092 krónikus C hepatitises beteg (175 szerotípus, 5917 genotípus) 1996 és 2017 közötti eredményét elemezzük típus/szubtípus, életkor, nem és a magyarországi régiókon belüli megoszlás alapján, valamint követjük a genotípusarányok két évtized alatti változását.

Módszer: Szerotípusvizsgálat (1996-1999). Genotípusvizsgálat: hibridizáció (2000-2016), real-time PCR-módszer (2016-; Cobas 4800 HCV GT).

Eredmények: A genotípusmegoszlás átlaga: GTla: 5,6\%; GTlb: 84,6\%; GTla + lb: 5,1\%; GT2: 0,1\%; GT3: 1,8\%; GT4: $0,1 \%$; vegyes: $1,6 \%$; GT1 (szubtípusa nem differenciált): $1,1 \%$. Nő : férfi $=52 \%: 48 \%$. A víruspozitív betegek 37\%-a az 50-60 éves korosztályba tartozott. A négy magyarországi régióban, valamint Budapesten és környékén jelentős genotípusaszimmetria nem igazolódott. A 3-as genotípus prevalenciája az utóbbi években 1,6\%-ról 2,8\%-ra emelkedett; a 40 év alattiakban megduplázódott a számuk.

Következtetés: Hazánkban 20 év alatt a HCV típus/szubtípus megoszlásában jelentős változás nem történt, jelenleg is az $1 / \mathrm{b}$ a leggyakoribb. Minőségi előrelépést hozott a real-time PCR-genotípusmódszer bevezetése, a kapott eredmények letisztultak, kevés közöttük a vegyes szubtípusú, ami a hatékonyabb gyógyszerválasztást segíti.

Orv Hetil. 2018; 159(Suppl 2): 2-8.
\end{abstract}

Kulcsszavak: hepatitis C-vírus, genotípus, szubtípus, valós idejú reverztranszkripciós polimeráz-láncreakció (RTPCR), hibridizáció, nukleotidszekvencia-analízis

\footnotetext{
Analysis of hepatitis $\mathrm{C}$ virus type and subtype distribution in Hungary

Introduction: Hepatitis $\mathrm{C}$ virus $(\mathrm{HCV})$ shows great structural variability. Based on genome sequencing and phylogenetical analysis, 7 types and 67 subtypes can be differentiated with varying geographical distribution. It is very important to determine the HCV type/subtype prior to starting direct antiviral therapy (DAA), which has been available since 2014, because the type, dose and optimal length of medication depends on these.

Aim: In Hungary, the treatment of chronic HCV patients started in 1992 with the relevant special diagnostic tests being carried out in our Molecular Diagnostic Laboratory. Determination of the nucleotide sequence of the Hungarian HCVIb NS5A/PKR-BR region and the type and subtype distribution of Hungarian patients have already been carried out. The current summary discusses the results of 6092 chronic HCV patients (175 serotypes, 5917 genotypes) based on age, gender, regions and genotype distribution changes over the period between 1996 and 2017. Method: Serotyping (1996-1999). Genotyping: hybridization (2000-2016), real-time PCR (2016-; Cobas 4800 HCV GT).

Results: Genotype distribution: GTla: 5.6\%; GT1b: 84.6\%; GTla + 1b: 5.1\%; GT2: 0.1\%; GT3: 1.8\%; GT4: 0.1\%; mixed: 1.6\%; GT1 (non-differentiated subtype): $1,1 \%$. Women/men ratio: $52 \% / 48 \%$. The most common age cate-
} 
gory is $50-60$ years (37\% of all cases). There was no genotype asymmetry among the four Hungarian regions and Budapest. Over time, the prevalence of genotype 3 increased from $1.6 \%$ to $2.8 \%$ and the number of patients under the age of 40 doubled.

Conclusion: There have been no substantial changes in the HCV type/subtype distribution in Hungary over the past 20 years, $\mathrm{lb}$ remaining the most common. The introduction of real-time PCR method for genotyping has resulted in a major quality improvement including only a few mixed subtype results leading to more efficient drug selection.

Keywords: hepatitis $\mathrm{C}$ virus, genotype, subtype, real-time reverse transcription-polymerase chain reaction (real-time RT-PCR), hybridization, nucleotide sequence analysis

Gervain J. [Analysis of hepatitis C virus type and subtype distribution in Hungary]. Orv Hetil. 2018; 159(Suppl 2): $2-8$

(Beérkezett: 2018. április 27.; elfogadva: 2018. május 11.)

\section{Rövidítések}

$\mathrm{DAA}=($ direct-acting antiviral agent $)$ direkt ható antivirális szerek; GT = genotípus; HCV = hepatitis C-vírus; ICTV = (International Committee on Taxonomy of Viruses) Vírustaxonómiai Nemzetközi Bizottság; IFN = interferon; ISDR = (interferon sensitivity determining region) interferonérzékenységet meghatározó régió; NS = nem strukturális; $\mathrm{RAV}=$ rezisztenciaaszszociált vírus; $\mathrm{RNS}$ = ribonukleinsav; $\mathrm{RT}-\mathrm{PCR}$ = reverztranszkripciós polimeráz-láncreakció; SVR = (sustained virological response) tartós virológiai válasz

Az 1989. év a jelenkori hepatológia fontos mérföldköve. Új molekuláris biológiai módszerekkel ekkor sikerült azonosítani az addig non-A-, non-B-hepatitisnek nevezett kórkép fó kórokozóját, a C-vírust [1]. Az azóta eltelt három évtized intenzív kutatásai feltárták a vírus szerkezetét, tisztázták a fertőzés patomechanizmusát. Szenzitív és specifikus diagnosztikai tesztekkel a betegség korai stádiumában felismerhető lett, hatásos antivirális gyógyszerekkel pedig ma már a krónikus C-hepatitis gyógyítható betegség.

\section{Vírusszerkezet}

A HCV genomja egyszálú, pozitív polaritású, 9,6 kb RNS-molekula, amely 9400 nukleotidból és lipidborítékból áll. Két végén 1-1 át nem íródó rész található (5'UTR, 3'UTR). 3010-3030 aminosavból álló poliproteint kódol, mely strukturális (core, E1, E2) és „nem strukturális” (NS2, NS3, NS4A/B, NS5A, NS5B) részeket foglal magában. Az utóbbiak enzimaktivitással rendelkeznek, és kiemelt szerepük van a vírusszaporodásban.

\section{Genotípusok}

A vírus felfedezése után rövid időn belül felismerték, hogy szerkezete nem egységes és nem stabil, nagy genetikai diverzitást mutat. Egyrészt a törzsfejlődés alatti mutációk következtében genetikusan heterogénné vált, másrészt a fertőzött betegben is változtatja szerkezetét. A legnagyobb variabilitást a 3'UTR, E1, E2, NS1/NS2 régiók mutatnak, a legstabilabbak az 5'UTR, core, NS5A, NS5B [2, 3]. A szerkezeti különbségek vizsgálata egyrészt epidemiológiai szempontból fontos, mivel következtetni lehet belőle a vírus származási helyére, tovaterjedésének módjára és útjára. Egyes típusai az egész világon elterjedtek ( $1 \mathrm{a}, 1 \mathrm{~b}, 2 \mathrm{a}, 2 \mathrm{~b})$, többnek viszont jellegzetes a földrajzi előfordulása $(5 \mathrm{a}, 6 \mathrm{a})[4]$.

Másrészt fontos szerepük van az antivirális terápiában, döntően befolyásolják a gyógyszerek hatását, ismeretük segít a gyógyszer típusának, a kezelés optimális időtartamának és a dózisnak a kiválasztásában.

Attól függően, hogy mely országban izoláltak egy-egy vírustípust, a szerkezeti azonosságtól függetlenül különböző elnevezéseket kaptak. Ennek a klasszifikációs „káosznak" a megszüntetésére 1994-ben P. Simmonds vezetésével egységes nevezéktant dolgoztak ki, melyen belül 1-6-os típusokat és a-c szubtípusokat különítettek el [5-7]. A típusok között 31-34\%-os, a szubtípusok között 20-23\% nukleotidszekvencia-különbséget határoztak meg. Az egy betegből izolált, 10\%-nál kevesebb eltérést mutató variánsok a „kvázispeciesek”.

A szekvenálótechnikák fejlődésével egyre nagyobb számú variánst ismertek meg, ezért 2005-ben új nómenklatúrát hoztak létre 6 típussal és 58 szubtípussal [8, 9]. Az ismert nukleotidszekvenciák nyilvántartása, rendszerezése és megújítása nemzetközi adatbázisokban történik: (NCIB) International Nucleotid Sequence Database, (DDBJ) General Data Database of Japan, (EMBL, Heidelberg) European Molecular Biology Laboratory, és a Los Alamos National Laboratory GenBank (Amerikai Egyesült Államok [USA]) [10]. A típus- és altípusneveket 2013-ban felülvizsgálták, valamint 1300 teljes HCV-genom szerkezet adataival bővítették az addigi klasszifikációt; 7 genotípus, 67 szubtípus és 21 elnevezés nélküli altípus került a rendszerbe, amely webfelületen elérhető, gazdája az International Committee on Taxonomy of Viruses (ICTV) [11, 12]. A nevezéktan újabb felülvizsgálata elengedhetetlenné vált a DAA-kezelések bevezetésekor és a sikertelen terápiák után kialakult re- 
zisztenciák (RAV) helyének pontos meghatározásához. A jelenlegi nómenklatúra 2017 júniusa óta érvényes (1. ábra).

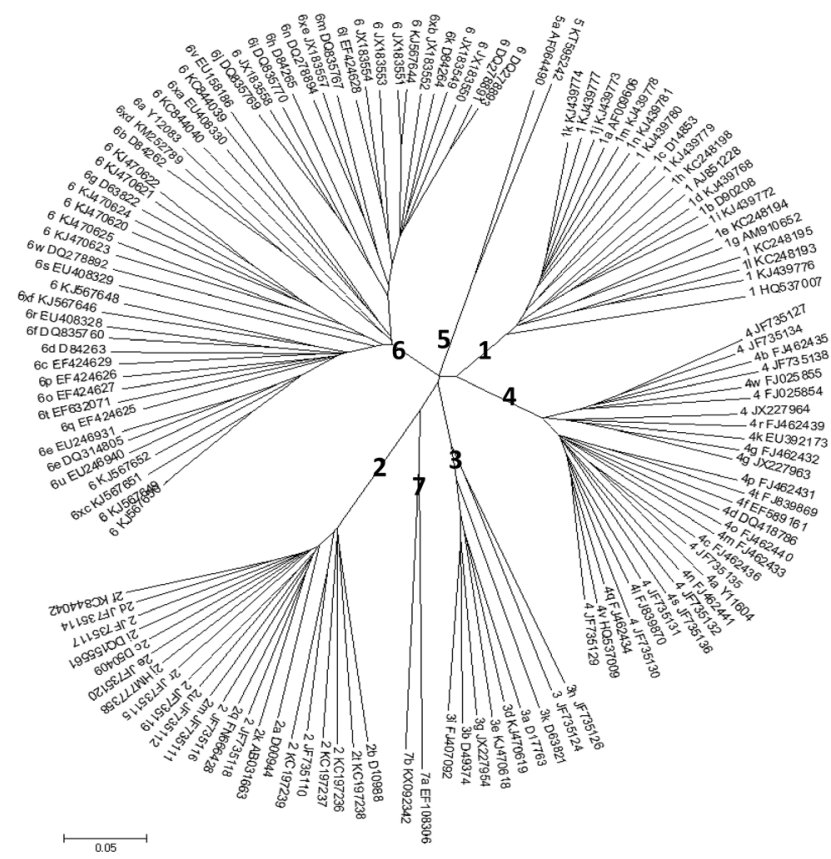

1. ábra

HCV-genotípusok és -szubtípusok rendszere (2017. június)
(International Committee on Taxonomy of Viruses)

\section{Diagnosztika}

A krónikus C-hepatitises betegek antivirális kezelése 1992-ben kezdődött el Magyarországon. Ennek lehetőségét a hepatológusszakma hatékony közbenjárására (képviselte: Gógl Á. és Telegdy L.) a magas költségú gyógyszerek központi finanszírozása teremtette meg. A kezeléseket végző májcentrumok betegei számára a speciális szerológiai és molekuláris diagnosztikai vizsgálatokat 1992 és 2008 között Molekuláris Diagnosztikai Laboratóriumunk biztosította [13]. 2008 óta a Szent László Kórháznak, 2013 óta a Semmelweis Egyetem (SE) Transzplantációs Klinikájának a laboratóriumával együtt azonos szenzitivitású tesztekkel és múszerekkel végezzük a terápiás és diagnosztikai protokollban elöírt vizsgálatokat [14].

A nagyobb országok és régiók már az 1990-es évek elején meghatározták a területükön előforduló HCV-típusokat, a magyar eredmények azonban hiányoztak. Kisszámú betegcsoport szérumát külföldi laboratóriumban vizsgálták, innen sejtettük, hogy nálunk fóleg az l-es típus található meg [15].

\section{Magyar betegek HCV szerkezeti analíziseinek eredményei}

Közleményünkben az 1996 és 2017 között végzett szerotípus- és genotípuseredményeink adatait mutatjuk be, melyeket több szempontból analizáltunk:

1. 1996: HCV-szerotípus-megoszlás.

2. A „magyar” HCVlb NS5A-régiójának nukleotidszerkezeti vizsgálata.

3. A HCV genotípus/szubtípus megoszlása. A statisztikai elemzés szempontjai:

a) A 2000 és 2017 között vizsgált genotípus megoszlása.

b) A különböző vizsgálómódszereknek a genotípuseredményeket befolyásoló hatása 2000-2015 és 2016-2017 időszakban.

c) A genotípusok életkori, nemi és országon belüli területi megoszlása.

\section{Eredményeink}

\section{Szerotípusmeghatározás}

1996-ban vezettük be a vírus szerotípusmeghatározását. 175 beteg mintáját vizsgáltuk (nő: 83, férfi: 92). Módszer: a HCV NS4-régiója elleni ellenanyag-vizsgálat; HCV serotyping 1-6 assay (Murex, Abbott) teszt, plateenzimimmunoassay módszer. Ezzel a vizsgálattal a vírus 6 fó típusát lehet differenciálni, hátránya, hogy szubtípusok meghatározására nem alkalmas. Immunhiányos betegekben, alacsony anti-HCV-ellenanyag-szintnél, hemodializáltaknál vagy blokkoló fehérjék jelenlétekor nem kapunk eredményt. Előnye, hogy gyógyult, HCVRNS-negatív betegeknél is meg lehet határozni utólag a fertőzést okozó vírus típusát.

Szerotípuseredmények: GT1: 75\%; GT2: 2\%; GT3: 1\%; GT4: $2 \%$; kevert típus: $8 \%(1+2 ; 1+3 ; 1+4$ és többszörösen vegyes); nem tipizálható: $4,5 \%$; nem adott reakciót: $7,5 \%$. A kevert típusok nagyobb részét politranszfundált betegekből vagy egészségügyi dolgozókból izoláltuk [16].

\section{A HCVIb nukleotidszekvencia-vizsgálata}

Az 1990-es évek közepén számos tanulmány jelent meg a világ különböző részein előforduló vírusok szerkezetéról. Japán kutatók közölték a náluk domináns GTlb teljesgenom-szekvenciáját, melyet HCVlb-J-nek (japán típus) neveztek el. Feltételezték, hogy ez a világban mindenütt előforduló lb-szubtípus referenciaszerkezete [17]. Öszszefüggést találtak a betegek interferonterápiára mutatott gyógyulási hajlama és a vírus NS5A-régiójában, a proteinkinázt blokkoló területen (PKR-BR) található, interferon- 


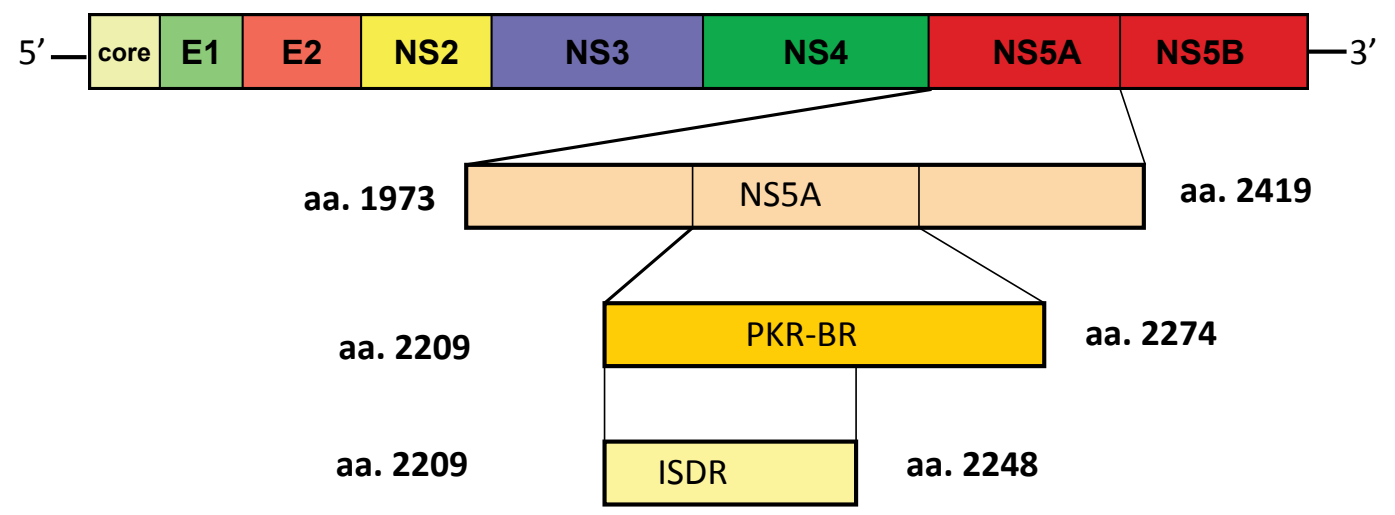

PKR-BR: RNS-függő-proteinkináz-kötő régió

ISDR: Interferonérzékenységet meghatározó régió

2. ábra |A HCV NS5A/PKR-BR régiójának aminosavterülete

érzékenységet meghatározó régiónak (ISDR) az aminosavváltozást okozó mutációi között (2. ábra). Mivel hazánkban is - Japánhoz hasonlóan - magas az lb-szubtípus aránya, meghatároztuk 21 krónikus hepatitises betegünkben a HCVlb NS5A-régiójának nukleotidszekvenciáját. Arra kerestünk választ, hogy a „magyar” lb-szubtípus azonos szerkezetü-e a „japán” prototípusú HCVlb-vel. Másrészt, lenne-e a gyógyulás előrejelzésében haszna, ha az antivirális kezelések előtt meghatároznánk ennek a régiónak a nukleotidszekvenciáját?

Módszer: HCV-genotípus-meghatározás Amplicor HCV 2.0 (Roche), INNO-LiPA HCV 2.0 (Innogenetics) és a HCVIb NS5A-régiója 2209-2274-es területének aminosav-szekvenciaanalízise.

Eredmény: Értékes információt kaptunk a magyar betegekből izolált vírusok szerkezetéről. (A minták aminosavszekvenciái AF 522299-522320-as sorszámon felvételre kerültek az NCBI - National Center for Biotechnology Information, Nemzeti Biotechnológiai Információs Központ, Bethesda, MD, USA - által fenntartott nemzetközi GenBank adatbázisba.) Megerősítettük, hogy a különböző földrészeken előforduló azonos szubtípusokon belül is jelentős szerkezeti eltérés található, ezek az úgynevezett „kvázispeciesek”, és más országok eredményeihez hasonlóan a „magyar” lb-vírus szerkezete is különbözik a japán szubtípusétól. Összefüggést találtunk a vizsgált területen lévő aminosavmutációk száma és az interferonterápiára kapott gyógyulási eredmények között, de ez nem bizonyult önmagában az egyetlen döntő faktornak.

\section{Genotípusmeghatározás}

A direkt nukleinsavvizsgálaton alapuló genotípus/szubtípus meghatározást 1999 óta végezzük [18]. Közleményünkben a 2017. év végéig vizsgált 5917 krónikus Chepatitises beteg eredményét elemeztük genotípus/ szubtípus, életkor, nem és a magyarországi régiókon belüli megoszlás alapján. Követtük a típusok arányának két évtized alatti módosulását. Kitérünk a laboratóriumi módszerek fejlődésének a kapott eredményekre gyakorolt hatására. Eredményeink 2008-ig az összes Magyarországon diagnosztizált krónikus C-hepatitises beteg típus- és szubtípusmegoszlását mutatják; 2009-től a vizsgálatokat a másik két laboratóriummal közösen végeztük, ettől az időtől eredményeink a magyarországi kezelt betegek 57\%-át reprezentálják.

\section{Módszerek}

A genotípusmeghatározásokat a molekuláris diagnosztika fejlődését követve egyre érzékenyebb és pontosabb tesztekkel végezzük. 1999 és 2006 között INNO-LIPA HCV II. (Innogenetics), 2009 és 2015 között pedig VERSANT HCV Genotype 2.0 Assay reverzhibridizációs módszerekkel vizsgáltunk, melyek a vírusnukleinsav 5'UTR- és 5'UTR + core régiójának szerkezete alapján 6 fó genotípus és a-c szubtípusok között differenciáltak [19]. A Cobas HCV GT (Cobas 4800; Roche) automatizált rendszerû real-time PCR-módszert 2016-ban vezettük be, amely a meghatározások pontosságában minőségi ugrást hozott. Az analízis alapja: $5^{\prime} \mathrm{UTR}+$ core + NS5B régió (3. ábra). Differenciál az 1-6-os genotípusok és az la/lb szubtípusok között. A teszt pontossága genotípusra 99,7\%, szubtípusra $100 \%$. A genotípuskimutathatóság alsó vírusszámhatára: GT2: $50 \mathrm{IU} / \mathrm{ml}$; GTla; lb; 3; 4; 6: $125 \mathrm{IU} / \mathrm{ml}$; GT5: 500 $\mathrm{IU} / \mathrm{ml}[20]$.

2000 és 2017 között 36 májcentrumból kaptunk mintákat. Magyarország területét önkényesen négy + Budapest és környéke régiókra bontottuk. Régiós beosztásunk:

Budapest és környéke: SE, Transzplantációs Klinika, Honvéd Kórház, Szent János Kórház, Uzsoki Kórház, Szent László Kórház, Kistarcsa. 
5'UTR: 2-es, 3-as és 6-os genotípus

Core-régió: 1-es, 4-es és 5-ös genotípus

NS5B régió: 1/a- és 1/b-szubtípus

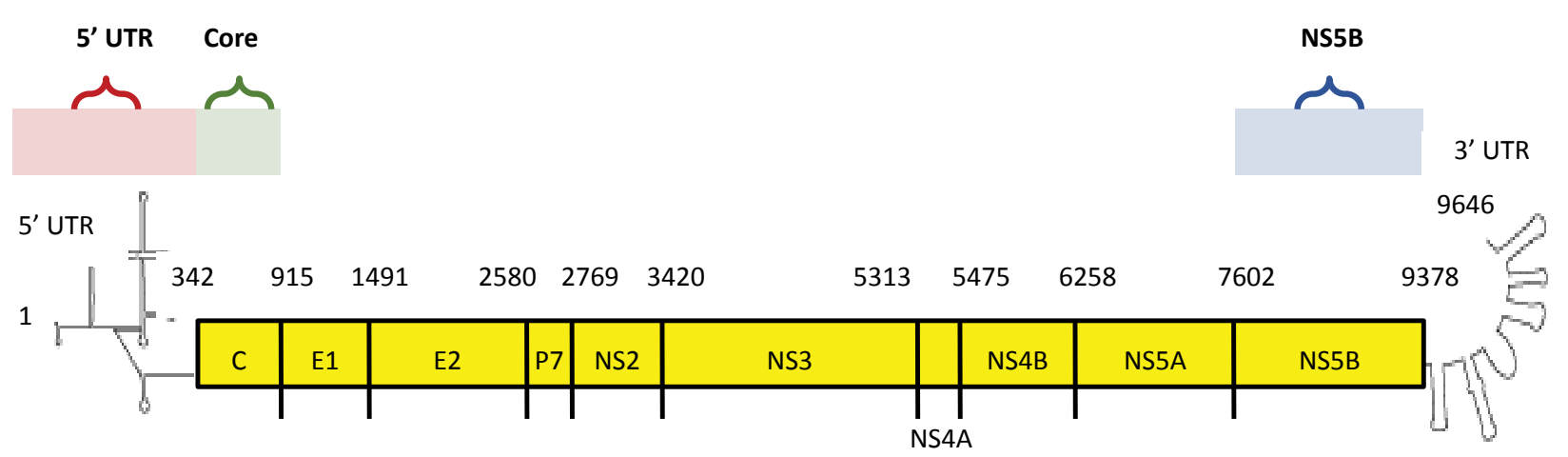

3. ábra | A HCV genotípus real-time RT-PCR-módszerrel történő meghatározásának molekuláris alapja (Cobas HCV 4800 System, Roche)

Eszak-dunántúli régió: Győr, Ajka, Mosonmagyaróvár, Sopron, Szombathely, Tatabánya, Székesfehérvár.

Dél-dunántúli régió: Pécs, Kaposvár, Szekszárd, Zalaegerszeg.

Északkeleti régió: Debreceni Egyetem, Kenézy Kórház (Debrecen), Miskolc, Eger, Szolnok, Nyíregyháza, Balassagyarmat.

Délkeleti régió: Szeged, Békéscsaba, Gyula, Kecskemét.

\section{Eredményeink}

1. Összgenotípus-megoszlás a 2000-2017. évben, betegszám: 5917 beteg (4. ábra és 1. táblázat):

GTla: 5,6\%; GTlb: 84,6\%; GTla + lb: 5,1\%; GT2: 0,1\%; GT3: 1,8\%; GT4: 0,1\%; vegyes: 1,6\%; GTl (szubtípusra nem differenciált): $1,1 \%$.

2. A genotípuseredményeket a két különböző módszertan alapján szétbontottuk (2. táblázat):

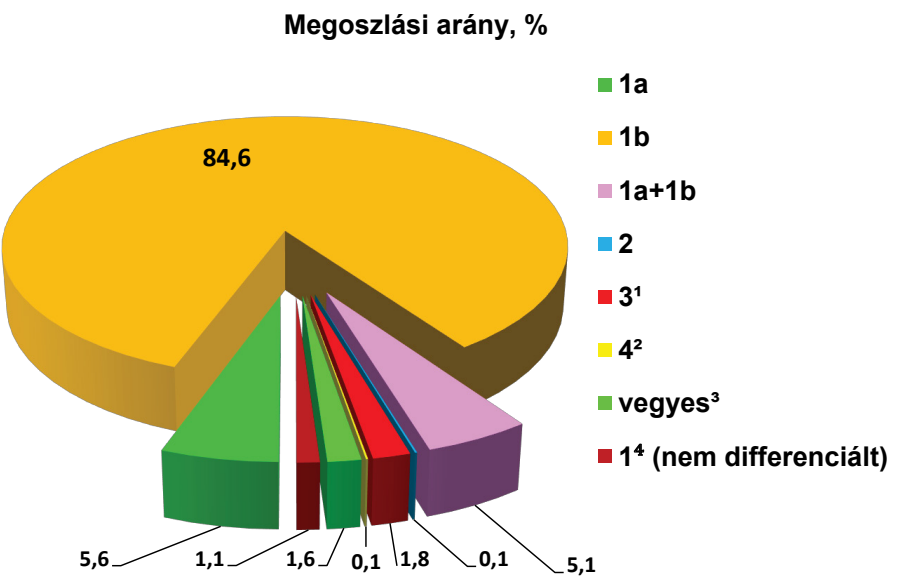

4. ábra $\quad$ A HCV genotípus/szubtípus megoszlása, 2000-2017 ( $\mathrm{n}=5917$ beteg)

1. táblázat | A HCV genotípus/szubtípus \%-os megoszlása Magyarországon (2000-2017) (n=5917 beteg)

\begin{tabular}{|c|c|c|c|c|c|c|c|c|}
\hline HCV genotípus/szubtípus & la & $1 b$ & $1 a+1 b$ & 2 & $3^{1}$ & $4^{2}$ & vegyes $^{3}$ & $\begin{array}{l}1^{4} \\
\text { (Nem differenciált })\end{array}$ \\
\hline $\begin{array}{l}\text { Megoszlási arány, } \% \\
\text { ( } 5917 \text { beteg) (2000-2017) }\end{array}$ & 5,6 & 84,6 & 5,1 & 0,1 & 1,8 & 0,1 & 1,6 & 1,1 \\
\hline
\end{tabular}

${ }^{1}$ Két iv. droghasználó beteg kettős fertőzöttséget mutatott: $3+1 b$

${ }^{2}$ Hibridizációs módszerrel a 4-es genotípusok mellett la-vagy lb-szubtípus is megjelent, real-time módszerrel (cobas 4800 ) vizsgálva tiszta 4-es genotípus igazolódott

${ }^{3}$ Hibridizációs módszerrel egy-egy betegben az la, lb, 2-es, 4-es genotípusok vegyesen kerültek

${ }^{4} \mathrm{Az}$ l-es genotípuson belül szubtípuseredményt nem differenciált a teszt 
2. táblázat | A diagnosztikai módszerek szerinti genotípusmegoszlás-eltérés

\begin{tabular}{|c|c|c|c|c|c|c|c|c|}
\hline Genotípus & la & $1 b$ & $1 a+1 b$ & 2 & 3 & 4 & $\begin{array}{l}\text { l } \\
\text { (nem differenciált) }\end{array}$ & $\begin{array}{l}\text { Vegyes } \\
(1 \mathrm{a}, 1 \mathrm{~b}, 2,4)\end{array}$ \\
\hline $\begin{array}{l}\text { 2000-2015. év } \\
\text { (betegszám n = 4844) }\end{array}$ & 294 & 4026 & 287 & - & 75 & - & 68 & 92 \\
\hline \%-os megoszlás & $6,1 \%$ & $83,1 \%$ & $5,9 \%$ & - & $1,6 \%$ & - & $1,4 \%$ & $1,9 \%$ \\
\hline $\begin{array}{l}2016-2017 \\
\text { (betegszám n = 1073) }\end{array}$ & 38 & 977 & 18 & 2 & 30 & 8 & - & - \\
\hline \%-os megoszlás & $3,5 \%$ & $91 \%$ & $1,7 \%$ & $0,2 \%$ & $2,8 \%$ & $0,8 \%$ & - & - \\
\hline
\end{tabular}

2000-2015: hibridizációs módszerek

2016-2017: real-time RT-PCR-módszer

a) 2000-2015. év, betegszám: 4844 beteg (2. táblá$z a t)$.

Eredmény: GTla: 6,1\%; GTlb: 83,1\%; GTla + lb: 5,9\%; GT3: 1,6\%; vegyes GT: 1,9\%; GT1 (szubtípusra nem differenciált): $1,4 \%$.

b) 2016-2017. év, betegszám: 1073 beteg.

Eredmény: GTla: 3,5\%; GTlb: 91\%; GTla + lb: 1,7\%; GT2: 0,2\%; GT3: 2,8\%; GT4: 0,8\%.

3. Életkori és nemi megoszlás (3. táblázat). A fertőzöttek 37\%-a az 50-60 éves korosztályban fordult elő.

4. Nő : férfi arány $=52 \%: 48 \%$.

5. A régiókat külön-külön elemezve a genotípusmegoszlásokban jelentős aszimmetriát nem találtunk.

Kiegészités: A Szent László Kórháznak és a SE Transzplantációs Klinikájának eredményei hasonló genotípusmegoszlást mutatnak (Újhelyi Eszter és Varga Marina személyes közlése alapján).

3. táblázat $\mid$ A krónikus C-hepatitises betegek életkor és nem szerinti megoszlása

\begin{tabular}{lcccccc}
\hline Életkor (év) & $<30$ & $30-40$ & $40-50$ & $50-60$ & $60-70$ & $>70$ \\
\hline \%-os megoszlás & $7,5 \%$ & $8,9 \%$ & $20 \%$ & $37 \%$ & $20 \%$ & $6,6 \%$ \\
\hline Nó $\quad(52 \%)$ & $3,2 \%$ & $3,4 \%$ & $9,2 \%$ & $21 \%$ & $11,2 \%$ & $4,0 \%$ \\
\hline Férfi $\quad(48 \%)$ & $4,3 \%$ & $5,5 \%$ & $10,8 \%$ & $16 \%$ & $8,8 \%$ & $2,6 \%$ \\
\hline
\end{tabular}

\section{Következtetés}

A nemzetközi adatok és a fertőzés kórlefolyásának ismeretében a Földön 70 millióra tehető a HCV-hordozók száma [21, 22]. Magyarországon ez 50-60 000 lakost jelent. A 2014. évben bevezetett 2. generációs DAA-készítményekkel - melyek 2018. január óta minden fertőzött számára elérhetőek - a kezeltek közel 100\%-a meggyógyítható. Ehhez két fontos feltételnek kell teljesülni. Egyrészt meg kell találni az eddig tünetmentes, nem kezelt „néma” vírushordozókat, tehát széles körü szưrésre van szükség [23-25]. Másrészt a gyógyszerekkel elérhető legmagasabb gyógyulási arányhoz a kezelések meg- kezdése előtt elengedhetetlen a vírusgenotípus meghatározása. Ezzel biztosítható az optimális gyógyszertípus, kezelési idő és dózis választása.

Vizsgálataink és a közleményünkben elemzett adatok az alábbiakat erősítették meg:

- A különböző földrészeken előforduló C-vírusok nukleotidszekvenciája azonos szubtípusokon belül is jelentős eltérést mutat, vizsgált betegeink genomszekvenálási eredményei is ezt igazolták.

- Magyarországon változatlanul domináló altípus a HCVlb, az eltelt 25 évben aránya érdemben nem változott.

- A GT3 az utóbbi években a 40 év alattiak között emelkedést mutat: $1,8-2,8 \%$.

- A különböző érzékenységű laboratóriumi módszerek használata jelentősen befolyásolja a kapott eredményeket. Hibridizációs technikával mért kevert, vegyes szubtípusú minták (3,3\%) real-time RT-PCR-módszerrel egyszeres, tiszta genotípusúaknak bizonyultak, ez jelentősen segíti a hatékony gyógyszerválasztást. (A minták egy része nukleotidszekvenálással kontrollált.) A néhány, két szubtípust mutató eredmény nagy valószínűséggel a beteg kettős fertőzöttségének következménye (például iv. droghasználóknál).

- Betegeink 37\%-a az 50-60 éves korcsoportból került ki.

- A nemi megoszlás kiegyensúlyozott.

- A genotípusok megoszlásában az országon belüli régiókban érdemi eltérést nem találtunk.

Anyagi támogatás: A közlemény Szupplementumként történő megjelentetését a Roche Magyarország Kft. támogatta.

A cikk végleges változatát a szerző elolvasta és jóváhagyta.

Érdekeltségek: A szerző előadói/tanácsadói dijban részesült az alábbi gyógyszer gyártóktól/forgalmazóktól: AbbVie, Fresenius-Kabi, MSD, Roche Magyarország Kft. 


\section{Köszönetnyilvánítás}

Kiemelt köszönet laboratóriumunk asszisztenseinek: Bakiné Hodovánszky Erikának, Kadlecsik Lidiának és Szabóné Barta Katalinnak a vizsgálatok pontos, precíz végzéséért, az adatok gyüjtésében és elemzésükben nyújtott segítségükért.

\section{Irodalom}

[1] Choo QL, Kou G, Weiner AJ, et al. Isolation of a cDNA clone derived from a blood-borne non-A, non-B viral hepatitis genome. Science 1989; 244: 359-362.

[2] Simmonds P. Variability of hepatitis C virus. Hepatology 1995; 21: 570-583.

[3] Smith DB, Pontisso P. Heterogeneity of hepatitis C virus. Baillieres Clin Gastroenterol. 1996; 10: 243-255.

[4] Dusheiko G, Schmilovitz-Weis H, Brown D, et al. Hepatitis C virus genotypes: an investigation of type-specific differences in geographic origin and disease. Hepatology 1994; 19: 13-18.

[5] Zeuzem S, Franke A, Lee J, et al. Phylogenetic analysis of hepatitis $\mathrm{C}$ virus isolates and their correlation to viremia, liver function tests, and histology. Hepatology 1996; 24: 1003-1009.

[6] Simmonds P, Holmes EC, Cha TA, et al. Classification of hepatitis $\mathrm{C}$ virus into six major genotypes and a series of subtypes by phylogenetic analysis of the NS-5 region. J Gen Virol. 1993; 74 : 2391-2399.

[7] Simmonds P, Alberti A, Alter HJ, et al. A proposed system for the nomenclature of hepatitis $\mathrm{C}$ viral genotypes. Hepatology 1994; 19: 1321-1324.

[8] Gower E, Estes C, Blach S, et al. Global epidemiology and genotype distribution of the hepatitis $\mathrm{C}$ virus infection. J Hepatol. 2014; 61: S45-S57.

[9] Lanini S, Easterbrook PJ, Zumla A, et al. Hepatitis C: global epidemiology and strategies for contol. Clin Microbiol Infect. 2016; 22: 833-838.

[10] Kuiken C, Simmonds P. Nomenclature and numbering of the hepatitis $\mathrm{C}$ virus. In: Tang $\mathrm{H}$. (ed.) Hepatitis C. Methods and protocols. Methods in molecular biology ${ }^{\mathrm{TM}}$, vol. 510. Humana Press, Totowa, NJ, 2009; pp. 33-53.

[11] Welzel TM, Bhardwaj N, Hedskog C, et al. Global epidemiology of HCV subtypes and resistance-associated substitutions evaluated by sequencing-based subtype analyses. J Hepatol. 2017; 67: 224-236.

[12] Smith DB, Bukh J, Kuiken C, et al. Expanded classification of hepatitis $\mathrm{C}$ virus into 7 genotypes and 67 subtypes: updated criteria and genotype assignment web resource. Hepatology 2014; 59: 318-327.

[13] Pár A, Gervain J, Gógl Á. Hepatitis C virus infection: pathogenesis, diagnosis and treatment. Scand J Gastroenterol Suppl. 1998; 228: 107-114.

[14] Hunyady B, Gerlei Z, Gervain J, et al. Screening, diagnosis, treatment and follow up of hepatitis $\mathrm{C}$ virus related liver disease.
National consensus guideline in Hungary from 22 September 2017. [A hepatitis C-vírus-fertőzés szűrése, diagnosztikája, antivirális terápiája, kezelés utáni gondozása. Magyar konszenzusajánlás. Érvényes: 2017. szeptember 22-től.] Orv Hetil. 2018; 159(Suppl 1): 3-23. [Hungarian]

[15] McOmish F, Yap PL, Dow BC, et al. Geographical distribution of hepatitis $\mathrm{C}$ virus genotypes in blood donors: An international collaborative survay. J Clin Microbiol. 1994; 32: 884-892.

[16] Gervain J, Simon G Jr, Papp I, et al. Analysing the type and subtype of hepatitis virus $C$ of chronic viral hepatitis patients in Hungary. [A magyarországi krónikus $\mathrm{C}$ vírushepatitises betegek vírustípus- és szubtípus-meghatározása.] Orv Hetil. 2001; 142: 1315-1319. [Hungarian]

[17] Gervain J. Gene diagnostics of the hepatitis B and C virus. [A hepatitis B- és C vírus gén diagnosztikája.] Orv Hetil. 2003; 144: 2547-2552.

[18] Gervain J, Simon G Jr, Simon J, et al. Genotype distribution of hepatitis $\mathrm{C}$ virus in the Hungarian population with chronic viral hepatitis C. Eur J Gastroenterol Hepatol. 2003; 15: 449-450.

[19] Zeuzem S, Rüster B, Lee JH, et al. Evaluation of a reverse hybridization assay for genotyping of hepatitis $\mathrm{C}$ virus. J Hepatol. 1995; 23: 654-661.

[20] Kessler HH, Stelzl E. Profile of Roche's cobas ${ }^{\circledR}$ HCV tests. Expert Rev Mol Diagn. 2017; 17: 311-319.

[21] Pawlotsky JM, Feld JJ, Zeuzem S, et al. From non-A, non-B hepatitis to hepatitis $\mathrm{C}$ virus cure. J Hepatol. 2015; 62(1 Suppl): S87-S99.

[22] Leblebicioglu H, Arends JE, Ozaras R, et al. Availability of hepatitis $\mathrm{C}$ diagnostics and therapeutics in European and Eurasia countries. Antiviral Res. 2018; 150: 9-14.

[23] Gervain J, Gógl Á. The success story of hepatology: 25 years of viral hepatitis C. [A hepatológia sikertörténete. A C-vírus hepatitis 25 éve.] Hepatol Gasztroenterol Szle. 2016; 2: 208-210. [Hungarian]

[24] Pár A, Pár G. Three decades of the hepatitis C virus from the discovery to the potential global elimination: the success of translational researches. [A hepatitis C-vírus (HCV) három évtizede a felfedezéstől a globális elimináció lehetőségéig: a transzlációs kutatás sikere.] Orv Hetil. 2018; 159: 455-465. [Hungarian]

[25] Hunyady B, Gervain J, Gógl Á, et al. National strategy to prepare eradication of hepatitis $C$ virus infection in Hungary. [Nemzeti program a hepatitis C-vírus-fertőzés magyarországi felszámolásának elókészítésére.] Medical Online 2015. november 06. (http://www.medicalonline.hu/cikk/nemzeti_program_a_ hepatitis_c_virus_fertozes_magyarorszagi_felszamolasanak_ elokeszitesere) [Hungarian]

(Gervain Judit dr., Székesfehérvár, Seregélyesi u. 3., 8000 e-mail: jgervain@mail.fmkorhaz.hu)

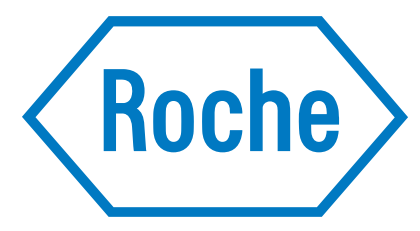

A kiadvány megjelenését a Roche (Mo.) Kft. támogatta. 